\title{
Financial liberalization index of Tunisia: Factorial method approach
}

\author{
Bouzid AMAIRA ${ }^{1}$, Radhia AMAIRIA ${ }^{2}$ \\ ${ }^{1}$ Faculty of Economics and Management of Tunis, University of Tunis El Manar, research laboratory "PS2D" \\ ${ }^{2}$ Faculty of Economics and Management of Sousse, University of Sousse \\ Email address: \\ am_bouzid@yahoo.fr(B.AMAIRA),na.zadou@hotmail.com (R. AMAIRIA)
}

\section{To cite this article:}

Bouzid AMAIRA, Radhia AMAIRIA. Financial Liberalization Index of Tunisia: Factorial Method Approach. International Journal of Economics, Finance and Management Sciences. Vol. 2, No. 3, 2014, pp. 206-211. doi: 10.11648/j.ijefm.20140203.11

\begin{abstract}
The objective of this paper is to construct an index of financial liberalization for Tunisia using the Principal Component Analysis method over a period of 33 years from 1980 to 2012. The index indicates the degree of financial liberalization at any given time. This index is especially useful to control the pace of liberalization and evaluation of the effect of this policy on economic aggregates. This paper also includes partial measures of liberalization index. The constructed index shows that the process of financial liberalization in Tunisia is accelerated with the introduction of the structural adjustment program, during the period 1987 to 1994.
\end{abstract}

Keywords: Financial Liberalization Index, Principal Component Analysis, Tunisia

\section{Introduction}

The process of financial liberalization in Tunisia began in 1987. Since then, various liberalization measures have been implemented to broaden and deepen the financial system. Some instruments were designed to increase competition and efficiency in the financial market. These instruments included the removal of barriers to entry, the commercial banks and the privatization of public banks. The monetary policy instruments such as the deregulation of interest rates, reducing reserve requirements and the change in the position of direct or indirect monetary policy were implemented. Similarly, the introduction of prudential norms, the establishment of finance companies and investment Banking revision of laws and the enactment of the law of debt collection aimed at ensuring the integrity of banks and maintaining Tunisian financial system stability . All these instruments were expected to achieve the overall objectives of the competition and the functioning of money markets and capital.

Financial liberalization is adopted worldwide through several elements reflecting the variety of restrictions has been previously taxed.

The most important are:

$\checkmark$ Elimination of the interest rate and other price controls,

$\checkmark \quad$ The privatization of state-owned intermediaries and reducing management
Administrative appropriations by public agencies,

$\checkmark \quad$ The administration of new entrants in all service industries financial and removal of legal protection for the cartel of financial markets,

$\checkmark$ Reductions in trade regulations on intermediate financial and

$\checkmark$ The tax reduction, explicit and implicit financial intermediaries.

These policy measures are presented below.

$\checkmark \quad$ Liberalization of interest rates (1987)

Although recently the control of interest rates is an aspect of growth and decline of government interventionism in the middle of the twentieth century, the ceilings on interest rates were a constant feature of several legal systems for these centuries. Relaxation of controls in the last quarter of this century was the first conduit, not by theory or ideology, but by the practical realities of increasingly unpleasant effects. In addition, the impact of high inflation on the basis supported in the 70s (accelerated by the abandonment of fixed exchange rates and the first oil shock) is a way of capping much nominal interest rate severely that screen.

Liberalization of domestic interest has been at the heart of financial reform programs in several emerging countries rate, largely due to the increasing evidence of adverse effects associated with financial repression. Positive real interest rates have two effects. On the one hand, they attract savings held outside the formal financial sector screen, which 
increases the resources available to the financial sector, increasing the level of investment and stimulating growth. On the other hand, these rates tend to discourage entrepreneurs to invest in low return projects that are no longer profitable at a high cost of loanable funds, therefore , the average yield or efficiency of the overall investment tends increase Fry (1997, $p$ 755).

It seems that the removal of the ceiling on interest rates provides better resource processing in stable means for financing investment. This thesis was developed by McKinnon (1973) and Shaw (1973) who attribute the difficulties emerging financial repression whose main form is exogenous and administrative fixing of ceiling interest rates. According to these authors, the distortions are causing the blockage of growth in emerging countries.

Thus, the rationale for liberalization of interest rates and their impact on the savings rate and the investment and therefore the way in which they affect growth which is called the hypothesis of complementarity between cash holdings and investment developed by McKinnon (1973). This hypothesis emphasizes the need for savings prior to investment and gives financial intermediaries mainly technical role. In which the increase in the quantity and quality of investment has positive effects on the growth rate of production and the liberalization of interest rate also plays an important role in the development of an interbank market and a secondary market for government securities that are required to control the business of money through open market operations.

$\checkmark \quad$ Privatization (1997) and elimination of direct credit control (1993)

Government controls on the financial system may also be exercised through ownership of a majority of institutions. Although it is difficult to find a country that does not have a financial system controlled by the state, today only the Central Bank (BC) among financial intermediaries is generally considered a natural candidate for the property the State. Indeed, the property of the state is seen by advocates of financial liberalization as an operation costs under pressure from shareholder loans and as deterioration in credit control functions.

Privatization of public financial institutions is considered a partial part of financial liberalization. In addition, the success of privatization operations, depending on the capacity of privatized banks, focused independent judgment in terms of performance, profit-seeking and distribution of credit.

In addition, the variety of capital flows frequently subjected to controls, is for policymakers, a less important instrument in the recommendations of the economic policy. These decision-makers seek to determine the optimal order of the liberalization process which avoids the occurrence of a financial crisis.

Policy makers have at their disposal the means of control imposed on different flows. Should determine the length (long or short term), the operation (input or output) and type (bank or otherwise) flows.

The main stream of bad debt is classified, has been solved by the regulation and supervision of banks, preventing emergency loans, and lower interest rates from stabilization. Solid money markets should enable authorities to more easily absorb hazards suffered by domestic liquidity. So it is necessary to remove controls on short-term borrowings from banks and non-banking institutions and to allow non -residents to influence domestic securities markets freely.

$\checkmark \quad$ Regulation and Supervision of Banks (1992)

The segmentation of the credit market, the lack of competition in the domestic banking sector, inadequate prudential regulation and inadequate controls have complicated the process of financial liberalization and prevented the achievement of expected results. As well as economic stability, regulation and prudential supervision are the conditions for successful financial liberalization. It is necessary to put in place rigorous programs of prudential regulation and supervision to minimize the "moral hazard" (including corruption, fraud and excessive risk taking ) in the banking sector at the end to ensure also variability and the health of the sector and finally at the end to improve the effectiveness of the liberalization of interest rates.

The main objective of regulation and prudential supervision of the banking sector is to achieve stability of the financial system, to obtain public confidence in that stability, manage systemic risk and protect clients. Insofar as the greater competition, increased market volatility is a customer of uncertainty after the deregulation and liberalization increases risk, the authorities need to strengthen prudential regulation and supervisory practices, especially as regards the requirements and capital ratios as regards the extent of the supervision of banks.

Similarly, prudential regulation encompasses the full range of risks to which the banking sector risks. Most often, it covers only the credit risk. Other risks, including those related to payment defaults, liquidity and interest rates should also be taken into account. Effective supervision must ensure that:

- The authorities responsible for monitoring have sufficient independence in relation to the political sphere,

- $\quad$ The regulatory framework in general is based on sound bases,

- The authorities responsible for supervision have adequate resources to hire, train and retain qualified personnel and to acquire appropriate technical,

- The authorities have sufficient power to ensure the application of their decisions and

- The supervision system balances the internal and external monitoring.

Improving regulation can also help avoid the problem of non- performing loans, the emergence of cross- borrowing between banks and affiliated companies and loan concentration in specific sectors.

The success of financial reform also depends on the good profitability of the private sector. In case of monitoring banks and ineffective in case of macro -economic instability, the liberalization of interest rates should proceed slowly and gradually to prevent any interference and disruption of financial contracts due to sudden removal of regulation these 
rates.

Following the emerging economies based on banks, banking regulation should be designed to limit the ability of banks to own businesses, to ensure wide distribution of ownership and control of banks and to limit lending in a sector particular whether the banking sector itself economically.

Financial regulation is also important to the health of the financial market. All regulatory environments for securities markets should provide comprehensive information about the companies and the external audit. In addition, the regulation of deception should be implemented before the liberalization of the capital market. So it is important to have an appropriate information system, but this element of the efficiency of the financial system is negligible in most emerging countries are characterized by a lack of complete and accurate information, and a lack of adequate accounting standards that involve the main obstacles to financial development in these countries. These obstacles to be solved require huge institutional reforms that have a solid infrastructure capable of providing an adequate information system, assessment and evaluation of credit.

Thus, information and transparency requirements are relevant factors that determine the efficiency of the securities markets. However, in most emerging markets, sources of reliable, accurate and publicly available information is scarce.

Faced with a stream of deregulation, globalization, financial innovation and technology diffusion in financial markets lead to increased competition and creates the appearance of new types of risks including currency risk and the risk of positioning operations on securities. In countries financially repressed banks, borrowers and lenders are not trained to deal with these risks. Financial liberalization should be accompanied by a strengthening of the surveillance of banks and the financial system, and must at the same time strengthen the ability of banks to evaluate new types of risks. $\checkmark \quad$ Barriers to entry (1993) and tax reform (1989)

The opening of the capital market depends on a serious budget consolidation and provision of instruments able to absorb the loss caused by the process of opening cash economy. A liberalized market requires instruments to avoid inflation and overvalued. Among these instruments, mention optimal management of the public debt, exchange rate and new application of monetary policy methods to try to align the interest rates on the international level.

In the short term, control of the state budget is done by the reduction in public spending on consumption and investment, the elimination of subsidies and privatization or closure of loss-making SOEs. A long-term control of this budget requires a tax reform favorable to the offer, either by broadening the tax base, and a simplification of tax structures, either by downward revision of tax rates to make them more competitive. Tax reform must also compensate for the loss caused by the removal of explicit and implicit taxes on financial intermediaries, mandatory for the elimination of controls on capital outflows do not result in leakage of the capital deletion.

The preparation and implementation of a tax reform, which gives rise to an economic and fiscal success depend on time appears insufficient in emerging countries and lead to a failure. In 1992, Fisher and Reisen show that the Indonesian tax reform implemented in 1983, seems an exception to this series of failures for the enlargement of the tax base (except oil), the reduction of tax rates and simplification of the tax system have succeeded in increasing ratios of tax revenue to GDP in several points.

Control of the state budget and tax reform does not immediately cancel the effects of budget deficits namely a massive public debt. Reducing barriers to entry capital destroys the ability of governments to maintain lower interest rates on government bonds when seeking to eliminate capital flight.

In the mid 70s, the banking function was easily industrialized making makes a profit. Thus, the admission of new entrants, including foreign entrants in the financial services industry and the anti -trust action against price fixing have played an important role in the liberalization of financial markets in industrialized countries and is beginning to be more universal in the developed world .

Increasing competitiveness can produce a simple gain efficiencies and innovations in improving services classification. These benefits are not insignificant, but the new freedoms sometimes lead to an increase or maintain market share pledge with banks seeking new entrants whose narrow margins and often unfamiliar territory may be undervalued.

Finally, it is necessary to observe that several checks in the past can be analyzed from a tax policy point of view. The ceiling of interest rates and the non- remunerated reserve requirements implicitly relate directly to substantial government or classes of borrowers, designated as preferred resources. Although financial intermediaries liquidate these quasi- taxes, and although they influenced the behavior of these intermediates, weights almost taxes are not necessarily lowered intermediately shareholders, but let through to customers depending on elasticities. Generally, the liberalization has result the reduction of the scale of financial sector taxation explicit and implicit.

\section{Construction of Financial Liberalization Index}

Financial liberalization is a process that involves the implementation of a number of policies as dictated above. To show the degree or level of financial liberalization at any given time, an index of financial liberalization (ILF) for Tunisia is constructed according to the method of principal components.

Bandiera, Caprio et al. (2000) and Laeven (2000) constructed an index of financial liberalization for eight developing countries including eight major components of financial liberalization in their index, which are (1) interest rates, (2) measures competitiveness, (3) reserve 
requirements, (4) credit control, (5 ) ownership of banks, (6) prudential regulation, (7) the financial market stock, and (8) the international financial liberalization.

Laeven (2000) constructed a similar index for 13 developing countries. It takes six financial liberalization measures but does not take measures related to stock markets and the external sector in its index.

Previously, Demetriades and Luintel (1997) constructed an index of financial repression for India using the method of principal components. They include nine different political repressions in their index.

Referring to the same optical Laurenceson and Chai (2003) constructed an index of financial repression similar to China.

With reference to our work, we build an index for Tunisia fiscal policy. In addition, we check the relationship between financial development indicators and the index. This variable is used as a proxy for financial liberalization. The calculation of this index is a qualitative exercise based on the type and year of liberalization. Thus, the construction of our index includes six different elements used in the process of financial liberalization, which are:

- Liberalization of interest rates;

- Introduction of mandatory reserves;

- Establishment of prudential regulation;

- Removal of barriers to entry in the banking and financial system;

- Remove the sectoral allocation of credit;

- $\quad$ Privatization of state banks.

The following table shows for the Tunisian banking and financial system the sequence of enforcement.

Table 1. The sequence of financial liberalization in Tunisia

\begin{tabular}{|c|c|c|c|c|c|c|c|}
\hline $\begin{array}{l}\text { Year of } \\
\text { measurement }\end{array}$ & 1980 & 1987 & 1989 & 1992 & 1993 & 1996 & 1997 \\
\hline Interest rate & & $\mathrm{x}$ & & & & & \\
\hline $\begin{array}{l}\text { Barrier to } \\
\text { entry }\end{array}$ & & & & & & $\mathrm{x}$ & \\
\hline $\begin{array}{l}\text { Reserve } \\
\text { requirements }\end{array}$ & & & $\mathrm{x}$ & & & & \\
\hline Credit control & & & & & $\mathrm{x}$ & & \\
\hline Privatization & & & & & & & $\mathrm{x}$ \\
\hline $\begin{array}{l}\text { Prudential } \\
\text { regulation }\end{array}$ & & & & $\mathrm{x}$ & & & \\
\hline $\begin{array}{l}\text { Total } \\
\text { measures } \\
\text { implemented }\end{array}$ & 0 & 1 & 2 & 3 & 4 & 5 & 6 \\
\hline
\end{tabular}

Source: IMF various reports and working papers, various reports of the World Bank, working papers and debate papers, Demirguc -Kunt and Detragiache (1998) and Luc Laeven (2000).

This table shows the sequence of financial liberalization with respect to each of six different measures. The crosses in the boxes indicate the year and the type of liberalization measures in question happens to effect. The number 2 indicates the implementation of two measures in 1989, and when we reach the number six (6) indicates that six (6) steps.

To take the index of financial liberalization, some arbitrary value is assigned to each financial liberalization policy (Table 2). Each liberalization variable can have a value between 0 and 6 . When a sector is fully liberalized, this variable takes a value of 1 and when the sector is regulated, it takes a value of 0 .

The description of the variables used in the construction of the index of financial liberalization and the date of implementation are presented below.

DTI: Deregulation of Interest Rates - 1987.

SBE: Removing Barriers to Entry - 1993.

RRR: reduction in compulsory reserve requirements - 1989.

RCC Relaxation in credit checks - 1993.

RBS: Regulation and Banking Supervision - 1992.

PSB: Privatization of State-owned Banks - 1997.

Table 2. Standard financial liberalization index

\begin{tabular}{llllllll}
\hline Year & DTI & SBE & RRR & RCC & RBS & PSB & LFI \\
\hline 1980 & 0 & 0 & 0 & 0 & 0 & 0 & 0 \\
1981 & 0 & 0 & 0 & 0 & 0 & 0 & 0 \\
1982 & 0 & 0 & 0 & 0 & 0 & 0 & 0 \\
1983 & 0 & 0 & 0 & 0 & 0 & 0 & 0 \\
1984 & 0 & 0 & 0 & 0 & 0 & 0 & 0 \\
1985 & 0 & 0 & 0 & 0 & 0 & 0 & 0 \\
1986 & 0 & 0 & 0 & 0 & 0 & 0 & 0 \\
1987 & 1 & 0 & 0 & 0 & 0 & 0 & 1 \\
1988 & 1 & 0 & 0 & 0 & 0 & 0 & 1 \\
1989 & 1 & 0 & 1 & 0 & 0 & 0 & 2 \\
1990 & 1 & 0 & 1 & 0 & 0 & 0 & 2 \\
1991 & 1 & 0 & 1 & 0 & 0 & 0 & 2 \\
1992 & 1 & 0 & 1 & 0 & 1 & 0 & 3 \\
1993 & 1 & 1 & 1 & 1 & 1 & 0 & 5 \\
1994 & 1 & 1 & 1 & 1 & 1 & 0 & 5 \\
1995 & 1 & 1 & 1 & 1 & 1 & 0 & 5 \\
1996 & 1 & 1 & 1 & 1 & 1 & 0 & 5 \\
1997 & 1 & 1 & 1 & 1 & 1 & 1 & 6 \\
1998 & 1 & 1 & 1 & 1 & 1 & 1 & 6 \\
1999 & 1 & 1 & 1 & 1 & 1 & 1 & 6 \\
2000 & 1 & 1 & 1 & 1 & 1 & 1 & 6 \\
2001 & 1 & 1 & 1 & 1 & 1 & 1 & 6 \\
2002 & 1 & 1 & 1 & 1 & 1 & 1 & 6 \\
2003 & 1 & 1 & 1 & 1 & 1 & 1 & 6 \\
2004 & 1 & 1 & 1 & 1 & 1 & 1 & 6 \\
2005 & 1 & 1 & 1 & 1 & 1 & 1 & 6 \\
2006 & 1 & 1 & 1 & 1 & 1 & 1 & 6 \\
2007 & 1 & 1 & 1 & 1 & 1 & 1 & 6 \\
2008 & 1 & 1 & 1 & 1 & 1 & 1 & 6 \\
2009 & 1 & 1 & 1 & 1 & 1 & 1 & 6 \\
2010 & 1 & 1 & 1 & 1 & 1 & 1 & 6 \\
2011 & 1 & 1 & 1 & 1 & 1 & 1 & 6 \\
2012 & 1 & 1 & 1 & 1 & 1 & 1 & 6 \\
\hline & & & & & & & \\
\hline
\end{tabular}

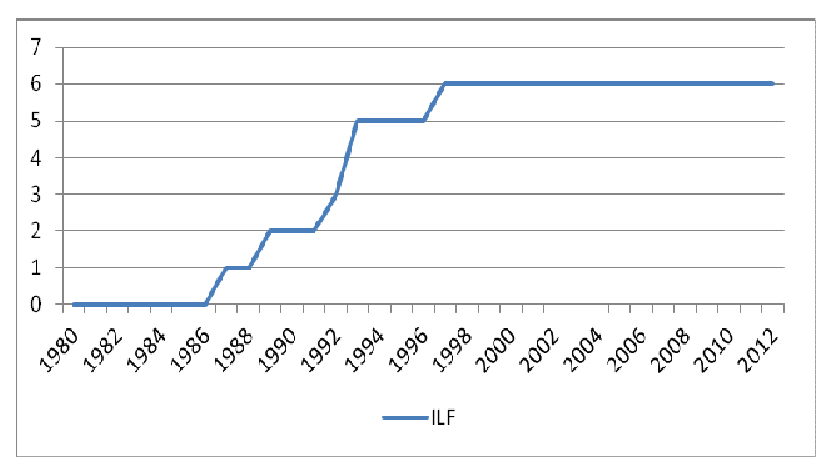

Figure 1. Indicator of financial policy for Tunisia 
Whereas some weaknesses of this indicator of fiscal policy, including zero for the years before the implementation of the financial reform values, it is necessary to improve the quality of this indicator and to better capture the effect on performance economic Tunisia. I therefore propose that the difference in our work (2003), an improved fiscal policy index.

From the values shown in Table 1 , the financial liberalization index (FLI) for Tunisia is achieved. For this purpose, the weight of each component is calculated using the method of principal components. The ILF of the composition can be expressed as follows:

$$
\mathrm{LFI}_{\mathrm{t}}=\alpha_{1} \mathrm{DTI}_{\mathrm{t}}+\alpha_{2} \mathrm{SBE}_{\mathrm{t}}+\alpha_{3} \mathrm{RRR}_{\mathrm{t}}+\alpha_{4} \mathrm{RCC}_{\mathrm{t}}+\alpha_{5} \mathrm{RBS}_{\mathrm{t}}+\alpha_{6}
$$$$
\mathrm{PSB}_{\mathrm{t}}
$$

In the above equation, $\alpha \mathrm{i}$ is the weight of the component given by the eigenvector corresponding to the selected main component. The eigenvalues and eigenvectors of the correlation matrix of the variables of financial liberalization policy are:

Table 3. Principal Component Analysis Results

\begin{tabular}{|c|c|c|c|}
\hline \multicolumn{4}{|c|}{ Matrix components } \\
\hline & \multicolumn{3}{|c|}{ Components } \\
\hline & 1 & 2 & 3 \\
\hline SBE & ,959 &,- 199 &,- 163 \\
\hline $\mathrm{ACC}$ & ,959 &,- 199 &,- 163 \\
\hline RSB & ,955 &,- 077 &,- 181 \\
\hline RRO & ,884 & ,370 &, 011 \\
\hline PBE & ,816 &,- 376 & ,438 \\
\hline DTI & ,796 &, 546 &, 150 \\
\hline \multicolumn{4}{|c|}{ Total variance explained } \\
\hline \multirow{2}{*}{ Components } & \multicolumn{3}{|c|}{ Extraction Sums of squares of the factors identified } \\
\hline & Total & $\%$ of the variance & $\%$ cumulative \\
\hline 1 & 4,833 & 80,546 & 80,546 \\
\hline 2 & ,662 & 11,031 & 91,577 \\
\hline 3 & ,301 & 5,010 & 96,587 \\
\hline
\end{tabular}

Take the first principal component which accounts for 80 percent of the total variance in all financial variables. Thus, the ILF is given by the following equation:

$$
\begin{array}{r}
\mathrm{LFI}_{\mathrm{t}}=0.796 \mathrm{DTI}_{\mathrm{t}}+0.959 \mathrm{SBE}_{\mathrm{t}}+0.884 \mathrm{RRR}_{\mathrm{t}}+0.959 \mathrm{RCC}_{\mathrm{t}} \\
+0.955 \mathrm{RBS}_{\mathrm{t}}+0.816 \mathrm{PSB}_{\mathrm{t}}
\end{array}
$$

The index for the individual components of the financial liberalization policy is calculated by substituting the values DTIt , BET , RROT , ACCT , and RSBT PBET equation ( 2) in Table 1 and multiplying by the respective values of $\alpha \mathrm{i}$. The index of financial liberalization for each year is calculated by adding the calculated values of all elements of the policy for the year concerned. The individual and total

\begin{tabular}{|c|c|c|c|c|c|c|c|}
\hline Year & DTI & SBE & RRO & $\mathrm{ACC}$ & RSB & PSB & LFI \\
\hline 1980 & 0 & 0 & 0 & 0 & 0 & 0 & 0 \\
\hline 1981 & 0 & 0 & 0 & 0 & 0 & 0 & 0 \\
\hline 1982 & 0 & 0 & 0 & 0 & 0 & 0 & 0 \\
\hline 1983 & 0 & 0 & 0 & 0 & 0 & 0 & 0 \\
\hline 1984 & 0 & 0 & 0 & 0 & 0 & 0 & 0 \\
\hline 1985 & 0 & 0 & 0 & 0 & 0 & 0 & 0 \\
\hline 1986 & 0 & 0 & 0 & 0 & 0 & 0 & 0 \\
\hline 1987 & 0,796 & 0 & 0 & 0 & 0 & 0 & 0,796 \\
\hline 1988 & 0,796 & 0 & 0 & 0 & 0 & 0 & 0,796 \\
\hline 1989 & 0,796 & 0 & 0,884 & 0 & 0 & 0 & 1,68 \\
\hline 1990 & 0,796 & 0 & 0,884 & 0 & 0 & 0 & 1,68 \\
\hline 1991 & 0,796 & 0 & 0,884 & 0 & 0 & 0 & 1,68 \\
\hline 1992 & 0,796 & 0 & 0,884 & 0 & 0,955 & 0 & 2,635 \\
\hline 1993 & 0,796 & 0,959 & 0,884 & 0,959 & 0,955 & 0 & 4,553 \\
\hline 1994 & 0,796 & 0,959 & 0,884 & 0,959 & 0,955 & 0 & 4,553 \\
\hline 1995 & 0,796 & 0,959 & 0,884 & 0,959 & 0,955 & 0 & 4,553 \\
\hline 1996 & 0,796 & 0,959 & 0,884 & 0,959 & 0,955 & 0 & 4,553 \\
\hline 1997 & 0,796 & 0,959 & 0,884 & 0,959 & 0,955 & 0,816 & 5,369 \\
\hline 1998 & 0,796 & 0,959 & 0,884 & 0,959 & 0,955 & 0,816 & 5,369 \\
\hline 1999 & 0,796 & 0,959 & 0,884 & 0,959 & 0,955 & 0,816 & 5,369 \\
\hline 2000 & 0,796 & 0,959 & 0,884 & 0,959 & 0,955 & 0,816 & 5,369 \\
\hline 2001 & 0,796 & 0,959 & 0,884 & 0,959 & 0,955 & 0,816 & 5,369 \\
\hline 2002 & 0,796 & 0,959 & 0,884 & 0,959 & 0,955 & 0,816 & 5,369 \\
\hline 2003 & 0,796 & 0,959 & 0,884 & 0,959 & 0,955 & 0,816 & 5,369 \\
\hline 2004 & 0,796 & 0,959 & 0,884 & 0,959 & 0,955 & 0,816 & 5,369 \\
\hline 2005 & 0,796 & 0,959 & 0,884 & 0,959 & 0,955 & 0,816 & 5,369 \\
\hline 2006 & 0,796 & 0,959 & 0,884 & 0,959 & 0,955 & 0,816 & 5,369 \\
\hline 2007 & 0,796 & 0,959 & 0,884 & 0,959 & 0,955 & 0,816 & 5,369 \\
\hline 2008 & 0,796 & 0,959 & 0,884 & 0,959 & 0,955 & 0,816 & 5,369 \\
\hline 2009 & 0,796 & 0,959 & 0,884 & 0,959 & 0,955 & 0,816 & 5,369 \\
\hline 2010 & 0,796 & 0,959 & 0,884 & 0,959 & 0,955 & 0,816 & 5,369 \\
\hline 2011 & 0,796 & 0,959 & 0,884 & 0,959 & 0,955 & 0,816 & 5,369 \\
\hline 2012 & 0,796 & 0,959 & 0,884 & 0,959 & 0,955 & 0,816 & 5,369 \\
\hline
\end{tabular}
index is calculated and presented in Table 4.
Table 4. Improved financial liberalization index for Tunisia

The figure of the index of financial liberalization (LFI) given in the last column of the table above is shown in Figure 2.

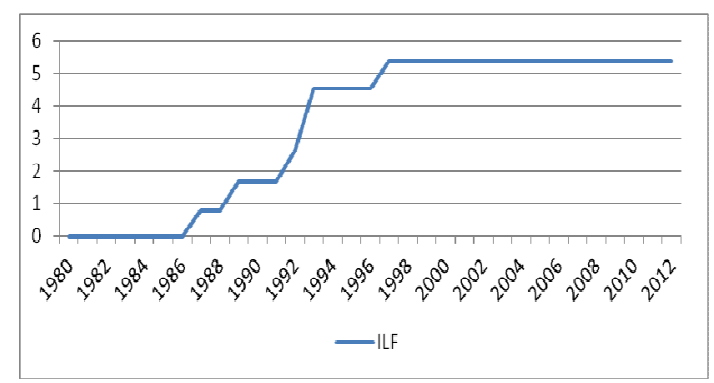

Figure 2. Financial liberalization index in Tunisia

The improved financial liberalization index is a composite index calculated from the regression of financial and monetary reforms, including the interest rates, reserve 
requirements, credit control, the bank privatization, elimination of barriers to entry and prudential regulation it is less interested in its value at its trend over time. The ILF is interpreted as follows: when the financial system is subject to measures of financial policy given the index of financial liberalization has a downward trend. By cons, when monetary authorities put in place a policy of financial liberalization, the trend of the ILF will be on the rise.

The chart above shows the index of financial liberalization evolution. Two main conclusions emerge: first, the evolution of the ILF reflects the impact of measures implemented by the monetary authorities. Indeed, over the period 1980-1986, the evolution of the index corresponds to the years during which the Tunisian monetary authorities pursued a policy of funding administered. Then, the level has risen since 1987, the year when the first financial liberalization measures were applied in Tunisia.

\section{Conclusions}

The index of financial liberalization in Tunisia was built in six steps involving different policies implemented during the liberalization process. The liberalization index is based on the factorial method.

Previous studies did not include this part correctly. Most previous studies treated the partial financial liberalization, full liberalization or excluded by taking the date of full liberalization. This is misleading, especially in the assessment of the impact. The index of financial liberalization in Tunisia shows that the decade 1987-1997 was the period during which most of the financial liberalization measures were implemented in Tunisia.

\section{References}

[1] Amaira B. (2003) : «Libéralisation financière et croissance économique : Approche en données de panel ", Communication lors de la 20ièmes Journées Internationales d'Economies Monétaire et Financière, BIRMINGHAM, 5 et 6 juin 2003, 20p.

[2] Bandiera O., Capio G., Honohan P. \& Schiantarelli F. (2000): «Does Financial Reform Raise or Reduce Savings? 》, Review of Economics and Statistics 82(2), pp. 239-263.

[3] Demirguc-Kunt A. et Detragiache E. (1998): «Financial Liberalization and financial fragility ", IMF Working paper series / WPS 1917, 48p.

[4] Demetriades P. \& Luintel K. (1997): «The direct cost of financial repression: evidence from India», The Review of Economics and Statistics, vol. LXXIX, n ${ }^{\circ}$, pp. 311-320.

[5] Fischer B. et Reisen H. (1992): «Vers la liberté des mouvements de capitaux», OCDE, 28p.

[6] Fry ML. (1997): «In Favor of Financial Liberalization », Economic Journal, $\mathrm{N}^{\circ} 107$, pp. 754-770.

[7] Laeven L., (2000): «Financial liberalization and financing constraints: evidence from panel data on emerging economics», The World Bank Working Paper $n^{\circ} 2467,50 \mathrm{p}$.

[8] Laurenceson J. and Joseph C.H. Chai (2003): «Financial Reform and Economic Development in China », Cheltenham, UK, Edward.

[9] Mc Kinnon RI. (1973): « Money and capital in economic development », The Brookings Institution, Washington.

[10] Shaw E.S. (1973): «Financial Deepening in Economic Development», Oxford University Press, New York. 